\title{
Professionalism and professional institutions in times of change
}

Article

Accepted Version

Hughes, W. and Hughes, C. (2013) Professionalism and professional institutions in times of change. Building Research \& Information, 41 (1). pp. 28-38. ISSN 0961-3218 doi: https://doi.org/10.1080/09613218.2013.737096 Available at https://centaur.reading.ac.uk/30313/

It is advisable to refer to the publisher's version if you intend to cite from the work. See Guidance on citing.

Published version at: http://www.tandfonline.com/doi/abs/10.1080/09613218.2013.737096

To link to this article DOI: http://dx.doi.org/10.1080/09613218.2013.737096

Publisher: Taylor \& Francis

All outputs in CentAUR are protected by Intellectual Property Rights law, including copyright law. Copyright and IPR is retained by the creators or other copyright holders. Terms and conditions for use of this material are defined in the End User Agreement.

\section{www.reading.ac.uk/centaur}

\section{CentAUR}

Central Archive at the University of Reading

Reading's research outputs online 


\title{
Professionalism and professional institutions in times of change
}

\author{
Will Hughes ${ }^{1}$ and Cathy Hughes ${ }^{2}$ \\ ${ }^{1}$ School of Construction Management and Engineering, University of Reading, Reading, RG6 6AW, \\ UK \\ email:w.p.hughes@reading.ac.uk \\ ${ }^{2}$ School of Real Estate and Planning, University of Reading, Reading RG6 6UD, UK \\ email: cathy.hughes@ reading.ac.uk
}

\begin{abstract}
Professionalism and professional institutions have developed and changed very gradually in recent decades, such that there are conflicting and competing definitions of what it means to be a professional. The direction of travel is examined through an institutional lens in terms of current trends and practices that have transformed professional life. At first sight, the evolution of professionalism appears to be developing into a new professionalism that requires less of professional institutions and more of the institutions of societal governance, such as contracts and statutes. These transformations are explored with reference to the need for a sustainable urban environment, showing that despite a reduced role of professional institutions, certain aspects of professionalism remain crucially important, especially in those jurisdictions where societal governance is not well developed. With the growing sophistication of legislation, insurance and commerce, the emphasis of what it means to be a professional is evolving. One key aspect of professionalism that is not usually listed in most texts is role definition and how this provides a sense of identity.

Professionalism remains a relevant and important concept, but the exigencies of a sustainable urban environment transcend the objectives of the professions and demand a broader, collaborative and participative agenda.
\end{abstract}

Keywords: built environment, economic development, governance, institutional theory, professional institutions, professionalism.

\section{Introduction}

The place of contemporary professionals and professional institutions within the built environment is examined from an institutional perspective. The professions under consideration here became established in the United Kingdom and the United States alongside industrialization and the rise of the 'culture of the market' (Larson 1977) in the $19^{\text {th }}$ Century. Associated with this development was the founding of the professional institution as an organization of practitioners within a specific field, with various characteristics such as barriers to entry, distinctive competence, codes of conduct etc. This has led to architects, surveyors and engineers holding positions of considerable esteem and influence not only within the domain of the built environment, but also within wider society. The primary question in this paper is whether these professions, as formally constituted in their professional institutions, are relevant (socio-) institutions ${ }^{1}$ given society's changing needs and expectations. Are they still required to fulfil the same roles, have they adapted or are they being displaced by new socio-institutions?

What it means to be a professional, and the nature of professional institutions is discussed using the ideas of institutional theory. This raises important questions about bodies of knowledge, role definitions, public interest and ethical conduct (cf Duffy and Rabeneck 2013; Hill et al. 2013). Connecting the current urgent and important preoccupations around sustainability with longer run 
changes in the way that professions are conceptualized, the current agenda for professionalism is portrayed as part of a consistent trend in how professions see themselves and are viewed by others. The argument leads to conclusions relating to the current and future roles of the professions in the built environment, with special attention being given to how they may need to adapt the exigencies of creating a sustainable urban environment.

\section{The institutional lens}

Institutional theory has its roots in economics, political science and sociology; from these founding roots emerge several different perspectives of socio-institutions. These can be best drawn together and summarized by saying that socio- institutions are durable, multi-faceted social structures; they are "composed of cultural-cognitive, normative, and regulative elements that, together with associated activities and resources, provide stability and meaning to social life" (Scott 2001: 48). Scott's conception is of three pillars of institutions; regulative, normative and cultural-cognitive. Institutions are seen to constrain and regulate behaviour (regulative), provide the value and moral dimensions of social life (normative) and to encompass shared conceptions by which social reality is constructed (cultural-cognitive). Of course, Scott is not referring specifically to professional institutions, but refers more widely to the institutional arrangements by which society is structured. Thus, this lens is not predicated on the existence of professional institutions, as such, and this implies that the functions of professional institutions, at least through an institutional lens, may be fulfilled by a variety of other means.

The professions can be considered in the light of this conception; over a considerable period of time they have each created their own cognitive and distinct framework with behaviours that they have internalized as second-nature, as well as their own distinct normative systems of rules and conventions determining how things should be done. However, all of this takes place within, and is influenced by, the wider frameworks of society (as elucidated by, for example, Meyer and Rowan 1977 and DiMaggio and Powell 1983). Therefore, institutions need social acceptability and credibility to survive (Scott 2001). This is known as legitimacy, a concept defined by Suchman (1995: 574) as: "a generalized perception or assumption that the actions of an entity are desirable, proper, or appropriate within some socially constructed system of norms, values, beliefs and definitions".

Professions in the built environment may have enjoyed legitimacy through the $20^{\text {th }}$ century. But, the primary question can be posed another way: do the built-environment professions still have legitimacy? In relation to the construction professions in particular, there are at least three constituencies of interest: the members of a profession, the professional institution and wider civil society. If dissonances between the perceptions of these constituencies become too great, the professional institutions may find that they are no longer seen as relevant and useful. As Scott (2001) notes, despite the definitional stability of socio-institutions, they can and do change and such change may be either evolutionary or revolutionary. Therefore, the primary question can be supplemented by asking how the professions should change if legitimacy has been weakened and whether such change is feasible.

These questions are approached by critically assessing key aspects of what it means to be a professional, looking particularly at those characteristics that have hitherto given the professions their raison d'être and their legitimacy. The extent of robustness and relevance for each aspect of the fabric of professionalism is considered in the light of recent and current developments in the commercial world and wider society.

\section{Defining a professional}

There is an extensive literature on the sociology of the professions (see the summaries by, for example, Elliott 1972, Sharma 1997, Evetts 2003). Elliott (1972) identified four basic defining 
characteristics in the way that the concept is usually used: a distinct body of knowledge, barriers to entry, serving the public and mutual recognition. Sharma (1997) synthesized the literature to define the professional as one who applies a body of knowledge and techniques acquired through training and experience, has a service orientation and distinctive ethics, and a great deal of autonomy and prestige. From her review, Evetts (2003) notes similar key features: exclusive ownership of an area of expertise and knowledge; the power to define the nature of problems as well as control over the access to solutions; the supportive professional community; autonomy; working for the public good (e.g. the wider or long-term public interest). The key aspects that have emerged from these various perspectives over the years are dealt with below in four areas: bodies of knowledge, role definition and a sense of identity, public interest and ethical conduct.

\section{Bodies of knowledge}

Knowledge is central to professions; it is their distinctive competence. As Scott and Backman put it, for professionals: "their primary weapons are ideas" (1990: 290). But, wider than this, professionals: "create cognitive frameworks that define arenas within which they claim jurisdiction and seek to exercise control" (Scott 2001: 129). Therefore, for example, Freidson's (1970) study of medical practices produced the observation that the right to control their own work is a characteristic peculiar to the professions. He developed this further (Friedson 2001), commenting on the wider professions and their direct control of terms, conditions, goals and content of their work. Dingwall (1983: 5) similarly observed that the professions: "can also set the very terms of thinking about problems which fall in their domain." As noted above, if a profession and its institution are to have continuing validity, then its members must surely be able to demonstrate the on-going relevance of their knowledge, their right to define it and all that flows from this, including the normative systems they set up around it.

\section{Judgement and knowing what is best for their clients}

Certainly, the knowledge required by a professional is typically seen to be far removed from the domain of the layperson. Larson (1977) observed that there was a common perception of professions having esoteric bodies of knowledge. In a similar vein, Freidson (2001) summarized the key features of the work of a professional as: "so specialized to be inaccessible to those lacking the required training and experience and the belief that it cannot be standardized, rationalized or... commodified" (p17). Is it still the case that professionals deal in such impenetrable ideas? Interestingly, 40 years ago, Haug $(1973,1977)$ argued that professionals were losing their position through a process of deprofessionalization. Haug argued that the inaccessibility to lay people of the knowledge at the heart of the professional's position was being eroded. Certainly since then, technology has led to information being accessible to laypeople along with software that will evaluate information inputs and suggest courses of action. Arguably, increased accessibility reduces the mystique of the professional and is likely to lead to a more critical appraisal of their position. By extension, the client, armed with freely available information, may not believe that the professional knows what is best. Goodman (1972: 246), for example, argued strongly for a more collaborative relationship between lay-person and professional expert: "[t]he crucial question here is not whether people can become technical experts in systems of building but whether or not people know enough about their own requirements for the use of architectural space to avoid being subservient to professionals". The distinction between personal judgements and expert technical advice is interesting in the light of how the professions seek to position themselves. Indeed, there is also evidence of this growing empowerment of users and clients from the medical professions, where medical practitioners are frequently confronted with patients who feel they know what is best, leading to serious concerns in medical circles about the deprofessionalization of clinical practice (e.g. Hardey 1999). Clearly, the idea that the professional knows what is best for the client is not a perception that is shared by all clients of professionals. 
However, as Freidson (2001) noted relatively recently, the professional is seen to be a specialist who can take abstract concepts and, in applying them, uses discretion. Arguably, it is in the impartial application of knowledge that professionals remain distinctive and that their approach to problems has validity. These skills enable them to deal with uncertainty and risk (Evetts 2003), especially if their work is backed up with insurance and the sanction of expulsion for those who fail to carry out satisfactory work. In other words, society still appears to place some value on an essential element of the professional's knowledge, which is subjective professional interpretation and evaluation based on experience.

\section{Controlling the body of knowledge}

An important aspect of the cognitive element of the professional institution is the control of what constitutes the corpus of knowledge. Certainly for Freidson (2001), the control of knowledge through formal training institutions is important to the professions themselves. While the built environment professional institutions historically provided their own training schemes, graduate entry schemes in the UK are now the standard entry route into the professions, meaning that the universities have a major input into the overall process. Importantly, they are not under direct control of the professions - but professional institutions do exercise a significant role in the accreditation of courses and curricula. Nor do the universities merely train and certify, they educate in a wider sense while the leading, research-driven institutions refine, expand and systematize the relevant body of knowledge and skill. Indeed, the best research into professional practices raises challenges that help to develop thinking and techniques in the professions. For example, the fragmentation and adversarial nature of the UK construction industry of the 1970s and 1980s was generally seen as a consequence of a series of political/economic developments such as antagonistic industrial relations, privatization, excessive sub-contracting, and labour casualization (Green, 2011).

While the direct influence of academic thinking on professional practice is, perhaps, exceptional, at a less formal level, the continuous dialogue between academia and practice offers the opportunity for critique and development. ${ }^{2}$ It may be argued that this kind of independent critical reflection reduces the chances of simply replicating traditional practices and belief systems that can become inappropriate as technologies develop and wider societal frames change. The current widespread debate on sustainable development throws the need for independent critical reflection into sharp relief; the professional knowledge base in the built environment requires new ideas from widespread sources, involving not only universities, but also governments, professions, businesses, occupiers and users of all kinds. A research-led university should have a role in enabling the next generation of professionals to be aware of and engage with the debate on changing belief systems and cultural frames. Therefore it may be that this is a mechanism by which both normative systems and cognitive frames are questioned and made relevant; this is not the automatic maintenance described by Jepperson (1991) which flows from the fact that the way of thinking within the socioinstitution is simply taken for granted and, therefore, perpetuated.

Of course, there is not a stark separation between academia and practice. Typically, the professions influence what the universities teach through a process of accreditation. A professional institution will only recognize certain programmes at particular universities whose course content is developed through various kinds of relationship between universities and professions. In this way, professions still take part in defining what universities teach to varying extents and so can ensure perpetuation of ideas and norms. Whether it is perceived to be a good thing or not, the relationships established for accreditation at least provide opportunities for a healthy tension between 'theory' and practice; they may even usefully slow the pace of change, reducing the impact of sudden jolts or wider shifts that are actually politically expedient changes of professional policy. The relationship between the professional institutions and universities, government and other stakeholders is, therefore, critical if 
the professions are to emerge as reflective as well as responsive to the issues and expectations of the $21^{\text {st }}$ century.

\section{Challenges to the professional's remit}

A pertinent question is to what extent the professions can and should shape and control their normative and cognitive frames. Evidence of this challenge is provided by Hill and Lorenz (2011) and Hill et al. (2013), who question how built environment professionals frame and address the issues within their domain. They focus on the valuation profession and argue that by focussing on meeting the short-term financial imperative of the client it means that the wider social and environmental context of valuation is disregarded. Hill and Lorenz advocate that the valuation profession should redefine what they do, arguing that, like any profession, they have the duty to challenge what the client or market is asking them to do. However, as currently defined by the profession, one of the primary tasks of a valuation surveyor is to assess market values as realistically as possible, in the context of real transactions. Any shift from this raises difficult issues as it introduces an ideological and normative perspective to the notion of market values; it takes the valuer into areas over which there is no professional consensus. Hill and Lorenz set out a challenge to the remit of the professional, which exemplifies the challenge to the legitimacy of the valuation profession to shape how they define problems. Similarly, Gilbertson and Preston (2005) highlight the changing demands of clients of the valuation profession. Clients are increasingly asking for much more than simple estimation of market value and they question whether the profession is up to the task. Crosby and Hughes (2011), in their discussion of valuation for secured lending, likewise argue for valuers to see their task differently, but they saw this not just as a problem for valuers to address, as they also make a plea for wider stakeholders (especially in the form of those attempting to review the UK banking system) to allow valuers to redefine their approach to better address the issues and problems around commercial property loans.

The challenge of sustainable urban development is taken up by Cooper (2009) who made it clear that the roles of planners, architects, engineers and constructors cannot continue to operate in professional silos of specific bodies of knowledge and habits of practice. Like Ball (1988: 57), Cooper (2009) described the emergence of the professions as a consequence of the division of labour, which itself is a necessary response to increasing complexity brought about by industrialization. Cooper (2009: 99) set out his position clearly from the outset: "[t]he very notion of sustainable development ... confronts the professions with serious challenges". Since the issue of sustainable development requires integrated, whole-systems thinking, Cooper went on to say that the disintegration of knowledge that defines separate professional institutions may be anathema to what is now needed. Cooper highlighted three major challenges to the professions in relation to sustainable development: competitive, collaborative and participative. The competitive challenge relates to threats to the existing order and competitive advantage of individual professions. Sustainable development requires new ways of framing problems and of working that may erode the traditional positions of the professions. The collaborative challenge relates to the need for cross-disciplinary skills and integrated decision-making skills that may eclipse traditional professional disciplines. The participative challenge, resonating with Goodman (1972), relates to the need for democratic, informed consent; such as the participation of communities in decisions that affect the way that they live. The challenges pose a serious threat the current constitution of the professions and may require a significant reassessment of the importance of professionalism in society.

Interestingly, Ball (1988: 62) drew attention to the "dilution of the professional exclusivity of architects and chartered surveyors", which happened in the 1980s as a result of economic and legislative changes. Perhaps the dilution is a trend, rather than an isolated event? This discussion leads to questions about the role that professionals are to fulfil, and the idea of what this means for 
the notion of professional identity, especially in response to the increasingly urgent agenda of sustainable development. Clearly, from the foregoing, the professions are not entirely in control of their bodies of knowledge. The emergence of new, research-based knowledge and the overriding urgency of the sustainability agenda presents a need for the professions to be rethinking their bodies of knowledge upon which their roles depend. This challenges the idea that professionals are autonomous in defining and framing what they do and leads to a conversation about roles; about what role a built environment professional fulfils in response to a rapidly changing world.

\section{Role definition and sense of identity}

The normative and cultural-cognitive frameworks that are central to the socio-institution of professions, largely through their professional institutions, provide role definition and give members a sense of identity. Not least this comes from the observation by Larson (1977) that the output of the professional is bound to the person and personality of the producer. This underlines the importance to the practitioner of being seen as a member of a profession. However, it is abundantly clear from the work of Brown and Phua (2011) that identities are socially constructed, personal and provisional. This means that the membership of a particular profession, while a key influence on the construction of an identity, is not the whole story. Identities are more subtle and personal than that, and they are not simply handed out by professional institutions, fully-cooked.

There are certain roles fulfilled by the professions that would not require a profession to continue, e.g. the role of the professional institution as a learned society, or its role as a community of practice. Both are wider than any individual occupational group and are found in many situations even some where a profession has not been identified. Comparison can be made with the experience in mainland Europe where professions are defined quite broadly. There, unlike in the UK and Northern America, identity is constructed (and status conferred) in relation to the nature of the employer, which is usually public sector, along with attendance at an elite academic institution (noted by Freidson 1994, Evetts 2003). So, while the Anglo-American professions play a very important role in constructing social identities and recognizing particular interests as important, in other parts of the world these phenomena are clearly not the exclusive domain of professions as they are now configured. But it is clear from experience in mainland Europe that, given the importance of phenomena like learned societies and social identities, there is always the potential for the professional institutions in providing some kind of identity and recognition. Within the Anglo-American purview, there are other phenomena that shape professional roles in the built environment: legislation, standardized contracts and professional indemnity insurance (PII).

In the UK, the state plays a role through legislation, such as the Restrictive Trade Practices Act 1976, which prevented the traditional practice of professional institutions in mandating specific terms of appointment and fee scales for their members. More specifically, The Architects Act 1997 relates to professional conduct of architects in the UK, and regulates who may use the title of architect. Apart from these Acts, self-regulation is a very important aspect of professionalism.

Roles are constrained because various national contract-drafting bodies, such as the Joint Contracts Tribunal (JCT) for the building industry, and the New Engineering Contract drafting committee for the Civil Engineering industry, involve representative groups who negotiate on the standardized terms and conditions of contract for construction work. Until relatively recently, the drafting of construction contracts and professional contracts were mutually exclusive activities, a practice roundly condemned in an influential government report by Latham (1994). Latham highlighted the problems caused by the professional team using a network of contracts, each of which was drafted independently, to privilege the position of the professional whose institute drafted it. This lead to incompatible obligations with some areas of responsibility omitted, or inadequately dealt with, at 
best. As a result, it has become more usual for the contracts of consultants to be part of a nationally negotiated suite of interlocking contracts whose objective is broader than that of each individual professional institution.

Ultimately, the decision about what a professional can or cannot do is taken by the providers of PII. With a strong and viable insurance market for professional decision-making, two things transpire: first, there is recourse for clients who have been dealt with negligently; second, insurers take on the role of deciding what kind of work and what kind of decisions the insured professionals may take on. Thus, for example, it may be difficult for an architect to specify innovative materials or components, if the insurers do not wish to take the risks inherent in untried solutions. There have been recent concerns within the surveying profession that an unwillingness to provide PII has reduced the number of firms willing to undertake valuations for secured lending. These concerns are such that, in December 2011 the Royal Institution of Chartered Surveyors (RICS) launched a consultation with its members with the intention of producing a report on the problems of risk and pricing of PII for professionals undertaking valuation.

Because their contracts are negotiated at national level, and because statutes are inescapable, and because acting without PII is considered unprofessional, there are major constraints on the kind of obligations that professional consultants in the built environment can take on. In other words, the institutional structure around these professional roles is somewhat inflexible. Together, these developments appear to have wrested control from the construction professions who traditionally used to specify their own terms of appointment, fee scales and scopes of work. Within the context of Scott's regulative pillar, there are two interesting aspects of the normative pillar that offer some key insights into the continuing role of the built environment professions. First, in the developing world, where legislation and legal recourse are not necessarily as comprehensive as they are in the developed world, the professions, through self-regulation, offer a powerful solution to the problem of appointing and remunerating reliable individuals to carry out tasks that rely on judgement and knowledge of the practitioner (a self-enforced solution to the problem of information asymmetry). Second, when governments anywhere are implementing ill-thought out or narrowly defined policies that threaten society or groups of individuals, professional institutions may be in a unique position to challenge, collectively, the actions or inactions of government, on behalf of society. Repressive or oppressive governments everywhere, according to Goodman (1972: 56) ought to find themselves challenged by the professions.

Indeed, there is evidence that support from stakeholders from the wider institutional environment is key to enabling and sustaining change and innovation (Scott 2001); see for example the study of innovation within schools undertaken by Rowan (1982). Cooper's (2009) participative challenge in relation to sustainable urban development requires new governance structures which demand increased lay involvement in decisions. As Luck $(2007,2009)$ has shown, there are techniques available for participatory design, but it is no easy step to create truly participative decision-making, rather than the kind of token consultation of the disenfranchised that was pilloried by Goodman (1972). The idea of increased lay participation in the decisions that affect them raises interesting questions about another aspect of professional life: working for the public good and with a wider, long term view, over and above the notion of personal betterment.

\section{Public interest}

A key feature of a professional institution is the commitment to maintain and promote the usefulness of the profession for the public advantage, i.e. to serve the public interest. As normative socio-institutions, professional institutions have traditionally been at the forefront of social agendas. Dingwall (1983: 5) noted that: "the professions presume to tell the rest of their society what is good 
and right for it." Parsons (1968) studied medical practices and was struck by the professional having an apparent denial of self-interest in order to serve society. In contrast, Goodman (1972: 247) argued that closed professional guilds that know better than the people they serve are anathema to a value system that seeks to create a better environment for ordinary people. He contended that architects and planners who held themselves out as knowing what was best for people caused feelings of alienation and marginalization that could ultimately lead to civil unrest. There was no perceived need to exclude the people from decisions about what was best for them. They did not need to be dependent on a professional for decisions about their urban environment, but as people grow more familiar with their urban environments through living in them, they should be expected to have some idea about their own requirements to avoid having to be subservient to professionals. While Goodman was referring to the relationships between planners/architects and the general population, this work from 1972 reveals that fundamental issues about professional life have been questioned for a long time. As Hill and Lorenz (2011) noted, the charter or constitution of professional institutions in the built environment are explicit in taking on an obligation to society in general but also the built environment in particular. While some may dispute that professionals necessarily have the trait of serving the public, nevertheless this characteristic is usually embedded within the objectives of a professional society. For example, this is true of the RICS, which is incorporated by a Royal Charter that sets out the objects of the organization. One of these objects is to maintain and promote the usefulness of the profession for the public advantage. ${ }^{3}$ Therefore, the interests of members are secondary to this, a fact which, in a members' organization such as a professional association, can lead to internal conflict. Yet, as Hughes (1958) noted, it is these normative systems that give the professions the licence to undertake activities from which others are barred.

Evetts (2003) noted that the reality of the professions is that they are now subject to closer scrutiny with targets and performance indicators and so have to be more commercially aware and managerial. Does this make it less likely that they will focus on serving the public interest and devalue their normative role? Evetts distinguishes those occupational groups that construct professionalism 'from within' rather than 'from above' (p. 409). While the latter case involves values imposed by employers and managers, the former (which arguably is more relevant to construction professions) allows the profession to construct its own identity with its own and the public interest in view.

There is certainly plenty of evidence of these bodies promoting sustainability, etc. Therefore, it might seem reasonable to assume that professionals, through their associations, are best placed to address failures within their respective markets, in particular the externalities that arise from the divergence between private and social costs and benefits. However, Crosby and Hughes (2009: 2627) reported, in relation to a UK Code of Practice on commercial leases, that members and officials of RICS and the Law Society were consistent in declaring that the client's interests came first. This resonates with an explicit declaration of the Architect's Registration Board (2009), the UK's statutory body responsible for determining who can be identified as an architect. In their Architects Code, Standard no 5 is, "[w] hilst your primary responsibility is to your clients, you should take into account the environmental impact of your professional activities". Similarly, the work by Hill and Lorenz (2011) on the valuation profession highlights the tensions that can occur between serving the client's interest and the public good. Their argument for widening the remit of valuation highlights the complexities around the interaction between the market and the social and environmental contexts, not least because of the lack of consensus in how to approach these aspects. Notions such as the public good or society's interests are not always clear and often inextricably linked to ideology; therefore it may be asking too much to expect a professional group to determine this and to respond accordingly. 
Perhaps this is why, as Hill and Lorenz (2011) noted, the environmental agenda gives responsibility to a diffuse group, which includes many organizations. Thus, the green environmental initiatives are not, in fact, led by the professional institutions. Such issues require a cross-disciplinary approach which the professions cannot, by definition, provide. This has led to the emergence of organizations such as the UK Green Building Council. The Royal Institute of British Architects (RIBA), the Chartered Institute of Building ( $\mathrm{CIOB}$ ) and various other professional institutions are members of this, alongside private sector organizations from a range of industry sectors, universities and interest groups among others. This raises an important question: are the issues today such that professions are no longer able to take the lead or to be the main players in these agendas?

Goodman (1972: 249) argued that: "to move this society to a sane use of its technology is a task of liberation obviously beyond the scope of any particular profession". These words written in response to the parlous state of the relationship between city planners and city dwellers in 1960s America seem to resonate very strongly with the needs for a sustainable built environment today. The passion evident throughout Goodman's book on planning and the built environment seems absent in much of the professional discourse on sustainability. If only it were possible to collectively sound a radical note for the professions along the lines of his concluding words: "[i]t is no longer possible for us to masquerade as 'disinterested', 'objective' professionals, applying our techniques with equal ease to those clients we agree with as well as to those we disagree with. We are, in effect, the client for all our projects, for it is our own society we are affecting through our actions. By raising the possibilities of a humane way of producing places to live, by phasing out the elitist nature of environmental professionalism, we can move toward a time when we will no longer define ourselves by our profession, but by our freedom as people." Perhaps the urgent agenda of sustainability is something to which this sentiment applies even more strongly than the planning, design and construction of urban environments was 40 years ago.

Indeed, the idea of placing the interests of the client above all else is tantamount to an abrogation of responsibility for professionals' actions. The idea of being an amoral and detached servant of the client goes against the fundamental tenets of professional institutions. Indeed, one can sympathize with Goodman (1972: 136) who asks: "is the professional really a tool of whatever system he [sic] operates in?" If one subscribes to the rhetoric of professionalism in relation to public interest, then should there be an expectation that exceeds the narrow achievement of their client's objectives? This raises interesting ethical questions.

\section{Ethical conduct}

While barriers to entry may be seen as ways of market protection in the Anglo-American tradition Evetts (2003), they can justifiably also been seen as mechanisms to prevent the unlicensed and uncontrolled exercise of practices that are dangerous in inexperienced hands. Inept medical practitioners are dangerous because they may kill their patients rather than cure them. Inept lawyers are dangerous because their incompetence may lead to innocent people being incarcerated and dangerous people going free. Inept architects and structural engineers are dangerous because their buildings may collapse and injure/kill people. The public needs to be protected from dangerous practitioners, hence the need for barriers to entry. Coupled with barriers to entry, there are also barriers to continuing practice, meaning that failure to conform to ethical standards of the profession may result in expulsion or some other sanction. This leads to the regulatory control of the professions, an aspect of socio-institutions often emphasized by institutional economists: "Institutions are the rules of the game in a society, or more formally, are the humanly devised constraints that shape human interaction" (North 1990: 3). 
A distinctive and continuing skill for which society relies upon professionals is impartial, subjective decision-making. The practice of a profession is a uniquely personal phenomenon, owned and practiced distinctively by each professional (as noted by Larson 1977). If all professionals were to consistently come to the same conclusion for a given set of circumstances, then there would be little need for the practice to be a profession. It is primarily this dependence on the subjective and experiential application of informed decision-making that requires a code of conduct (as explicitly identified, for example, in the RIBA Code of Professional Conduct 2005). Professional codes of conduct are basically about integrity, honesty, competence, respect for people and the environment. Professional institutions make clear that conformance with such codes is mandatory for members and abuse of codes is reason to be expelled from the profession. This suggests that the profession is best placed to determine what happens when one of their own is accused of negligent decision-making. After all, it is not in the interest of the professional body to be too protective towards its members, because in the long run the reputation of the whole profession would suffer. The point about a professional institution is that it is more important than any of its members. However, as Scott (2001) noted, the design and operation of any regulatory system is not straightforward or free of controversy. Rules, even within Codes of Conduct, may be ambiguous and so require interpretation; disputes must be resolved; incentive systems and sanctions must be designed. So, as Suchman and Edelman (1996) set out, the regulative aspect of socio-institutions relies on cultural-cognitive and normative as much as on coercive elements. This brings us back to Dingwall's (1983) characterization of a profession thinking it knows what is good for society, and also how to define and address problems within its domain.

Maybe, therefore, it is no surprise that O'Neill (2002), in a discussion about trust in society generally, points to a growing distrust of the professions and brings into question the practice of the professions making judgements about conformance issues. Indeed, Pierce (2007: vi) in a comprehensive literature review, identifies substantial criticisms about the "integrity, independence, public service and ethical standards" that bring the accountancy profession into disrepute. While the most serious and high-profile exposés of unprofessional conduct have come from such professions, it is unlikely that other professions can remain untainted in the public perception.

While this is compelling, and such codes are laudable, nevertheless it is interesting to question the continuing need for them, especially as there are newly industrialized countries that have not yet developed the panoply of professional institutions that exist in somewhere like UK. To address this, it is appropriate to consider what would happen in the absence of systematic professional ethics. Alternatively, if there were a trend away from a reliance on professionalism, what kind of mechanisms would develop to fill the vacuum, or to deal with those areas where there are no techniques for safeguarding clients and society? One answer may reside in modern commercial governance. Any organization of an appreciable size could arguably be said to share similar value systems to those espoused by the professions. The notion of corporate social responsibility (CSR) and the need for organizations to deal with reputation management clearly connect to the same agenda. As Green et al. (2008) pointed out, the CSR agenda is an interesting response to the kind of unregulated enterprise culture that has often been seen to be so destructive in society. CSR is about the way that a business seeks to comply with the spirit of the law, with ethical conduct and with international standards. Increasingly, sustainability is seen as the driving force of the CSR agenda. In other words, in the absence of professional codes of conduct, perhaps socially aware business clients would derive competitive advantage by regulating themselves in this way. Whether this is better or worse, or even whether it works, is debatable, but there are two interesting ideas that flow from this discussion. First, if the ethical codes of the professions are inadequate to their tasks, the regulation and enforcement of ethical conduct would not necessarily completely disappear, because their clients would demand conformance with CSR requirements. On the other hand, in those countries that are still developing, legal systems may not be as sophisticated or even respected as 
they are in the developed world. Thus, the current brand of professionalism that includes ethical codes of conduct buttressed by self-enforced sanctions is extremely popular in those jurisdictions. This has undoubtedly contributed to the surge in membership of institutions like the RICS and CIOB in many developing countries where CSR has yet to emerge.

\section{Conclusions}

The professions and the professional institutions in the built environment emerged alongside industrialization. The central question is whether they are still relevant today, particularly in the light of the burgeoning sustainability agenda. The institutional lens offers insights into the relationships between professions and other institutions of society, providing a theoretical context for the discussion in this paper. The legitimacy of the established built environment professions is an important defining characteristic that underpins the primary and secondary questions explored in this paper.

Scott's three pillars of institutions (regulative, normative, cultural-cognitive) provide a robust basis from which to discuss key elements of what it means to be a professional (bodies of knowledge, role definition, public interest, ethical conduct). Although role definition and a sense of identity are not usually included as defining characteristics of the professions, their emergence in this discussion provides a powerful link between what professionals know and what they do. Contrary to most of the literature on professionalism which argues that professionals enjoy the privilege of directly controlling the terms, conditions, goals and content of their work; it has been revealed that, at least in the built environment, this privilege is illusory. This is due to the constraints of nationally negotiated terms of appointment, statutory controls and professional indemnity insurance. Moreover, it has been argued that the sustainability agenda means that a professional institution that claims exclusive ownership of a specific body of knowledge loses legitimacy. Indeed, the sustainability agenda shows the need to work across professions and have a wider remit, involving a much broader constituency of stakeholders in participative roles, even to the extent of shaping the questions that professionals are dealing with. Thus, the kind of control that professionals have over their roles and bodies of knowledge is not what it once was, and is likely to continue to weaken.

The rise of professional institutions in emerging economies points to a particular kind of sociopolitical environment in which some of the key concepts underpinning professionalism have a strong legitimacy. These aspects revolve around ethical codes and self-regulation which may fill a vacuum in some jurisdictions.

Public interest is a crucial source of professional institutions' legitimacy. However, this does not mean that is acceptable for professionals to presume to know what is best for all stakeholders. While this seemed a radical stance in the 1970s, it is increasingly common for ordinary people to insist on participation and consultation as a right when professional decision-making affects their lives. The sustainability agenda adds momentum to this trend as no single profession or group can plausibly respond to the problems confronting society. Public interest demands a cross-disciplinary approach with participation of diverse stakeholders. Thus, the meaning of public interest is changing. The emergence of corporate social responsibility has not generally transformed major companies into paragons of ethical behaviour. But the demands of business clients are likely to increasingly centre around CSR requirements.

Professional institutions remain highly relevant in society, generally, and in the property and construction sectors, specifically. However, their roles have changed in recent decades. 
Overall, the future for the professions is not bleak, but is certainly challenging. The transformative processes that they are going through will not diminish the importance of professionalism in society, but these processes will change the way that professionals are perceived and employed. The growth of interest from developing countries in various construction professions shows that the role of professionals is likely to remain relevant and of central importance in the world. This is likely to continue; not least because the sustainability agenda will require high levels of technical expertise and professional judgement in cross-disciplinary groups of diverse stakeholders. The built environment professions will play an important role in this agenda, but only if they can rise to the challenges and evolve new conceptions of professionalism.

\section{References}

Architects Registration Board (2009) The architects code: standards of professional conduct and practice, Architects Registration Board, London.

Ball, M (1988) Rebuilding construction: economic change in the British construction industry, Routledge, London.

Brown, A D and F T T Phua (2011) Subjectively construed identities and discourse: towards a research agenda for construction management. Construction Management and Economics, 29(1), 83-95.

Centre for Strategic Studies in Construction (1988) Building Britain 2001. Centre for Strategic Studies in Construction, University of Reading, Reading.

Cooper, I (2009) Sustainable urban development and the professions in the UK. In: I, Cooper and M Symes (Eds.) Sustainable urban development volume 4: changing professional practice. Routledge, London, pp. 99-126.

Crosby, N and C Hughes (2009) Monitoring the 2007 Code for leasing business premises, Department for communities and local government, London.

Crosby, $\mathrm{N}$ and $\mathrm{C}$ Hughes (2011) The basis of valuations for secured commercial property lending in the UK. Journal of European Real Estate Research 4(3), 225-242.

DiMaggio, P J and W W Powell (1983) The iron cage revisited: institutional isomorphism and collective rationality in organizational fields. American Sociological Review 48(2), 147-160.

Dingwall R (1983) Introduction. In: R Dingwall and P Lewis (Eds), The sociology of professions. New York: St Martin's Press, 1-13.

Duffy, F. and Rabeneck, A. (2013) Professionalism and architects in the the $21^{\text {st }}$ century. Building Research \& Information, 41(1), 115-122.

Egan, J (1998) Rethinking construction: the report of the Construction Task Force to the Deputy Prime Minister, John Prescott, on the scope for improving the quality and efficiency of UK construction, Department of the Environment, Transport and the Regions Construction Task Force, London.

Elliott, P (1972) The sociology of the professions. Macmillan, London.

Evetts J (2003) The sociological analysis of professionalism: Occupational change in the modern world. International Sociology 18(2), 395-415.

Freidson, E (1970) Profession of medicine: a study of the sociology of applied knowledge. Dodd, Mead, New York, NY.

Freidson, E (1994) Professionalism reborn: theory, prophecy, and policy. University of Chicago Press, Chicago, IL. 
Freidson, E (2001) Professionalism: The third logic. Polity, Cambridge.

Gilbertson, B and D Preston, (2005) A vision for valuation, Journal of Property Investment and Finance, 23(2), 123-140

Goodman, R (1972) After the planners. Penguin, Harmondsworth.

Green, S D (2011) Making sense of construction improvement. Wiley-Blackwell, London.

Green, S D, Harty, C, Elmualim, A A, Larsen, G D and Kao, C C (2008) On the discourse of construction competitiveness. Building Research \& Information, 36(5), 426-35.

Hardey, M (1999) Doctor in the house: the internet as a source of lay health knowledge and the challenge to expertise. Sociology of Health and IIIness, 21(6), 820-35.

Haug, M R (1973) Deprofessionalization: an alternative hypothesis for the future. The Sociological Review Monograph, no.20, 195-211.

Haug, M R (1977) Computer technology and the obsolescence of the concept of profession In: M.R. Haug and J. Dofny (eds) Work and technology, Sage, London, 215-228.

Hill, S and D Lorenz (2011) Rethinking professionalism: guardianship of land and resources. Building Research \& Information, 39(3), 314-319.

Hill, S., Lorenz, D., Dent, P. and Lützkendorf, T. (2013) Professionalism and ethics in a changing economy. Building Research \& Information, 41(1), 8-27.

Hughes, E C (1958) Men and their work. Free Press of Glencoe, London.

Jepperson, R L (1991) Institutions, institutional effects, and institutionalization. in The new institutionalism in organizational analysis, edited by W.W. Powell and P.J. DiMaggio. University of Chicago Press, Chicago, IL, pp. 143-163.

Larson, M S (1977) The rise of professionalism: A sociological analysis. University of California Press, Berkeley, CA.

Latham, M (1994) Constructing the team: final report of the government/industry review of procurement and contractual arrangements in the UK construction industry, HMSO, London.

Luck, R A C (2007) Learning to talk to users in participatory design situations. Design Studies, 28(3), 217-42.

Luck, R A C (2009) 'Does this compromise your design?' Interactionally producing a design concept in talk. Co-Design: International Journal of Co-creation in Design and the Arts, 5(1), 21-34.

Meyer, J and B Rowan (1977) Institutionalized organizations: formal structure as myth and ceremony. American Journal of Sociology 83, 340-363.

National Economic Development Office (1983) Faster building for industry. HMSO, London.

National Economic Development Office (1988) Faster building for commerce. HMSO, London.

North, D C (1990) Institutions, institutional change, and economic performance. Cambridge University Press, Cambridge.

Parsons, T (1968) The structure of social action. Free Press, New York, NY.

Pierce, A (2007) Ethics and the professional accounting firm: a literature review. The Institute of Chartered Accountants in Scotland, Edinburgh.

Rowan, B (1982) Organizational Structure and the Institutional Environment: The Case of Public Schools. Administrative Science Quarterly 27(2), 259-279. 
Scott, W R and E V Backman (1990) Institutional theory and the medical care sector. in Innovations in healthcare delivery: Insights for organization theory, edited by S.S. Mick. Jossey-Bass, San Francisco, CA.

Scott, W R (2001) Institutions and organizations, Sage, Thousand Oaks, CA.

Sharma, A (1997) Profession as agent: Knowledge asymmetry in agency exchange. Academy of Management Review, 22, 758-798.

Suchman, M C (1995) Managing Legitimacy: strategic and institutional approaches. The Academy of Management Review, 20(3), 571-610.

Suchman, M C and L B Edelman (1996) Legal rational myths: the new institutionalism and the law and society tradition. Law and Social Inquiry, 21(4), 903-941.

\section{Endnotes}

${ }^{1}$ To avoid confusion, the wider concept of institution as 'socio-institution' is used hereafter and this refers to an association of professionals as 'professional institution'.

2 In parallel with government reviews on construction sector improvement (for example, National Economic Development Office $(1983,1988)$, the University of Reading lead a series of reports resulting in key recommendations relating to integration, teamwork and partnerships, challenging existing working practices at all levels in the construction sector, including the professions (Centre for Strategic Studies in Construction 1988), which is often seen as the precursor to review of organization, management and contracting in construction by Latham (1994) and, subsequently, Egan (1998).

${ }^{3}$ Of course, the granting of a Royal Charter is dependent upon certain requirements that go along with the charter, and public interest is one of them. 